\title{
Erotismo e política: em torno de algumas figurações femininas na transição do romantismo ao realismo poético
}

\author{
Vagner Camilo
}

\begin{abstract}
Resumo: O presente ensaio tem por objetivo examinar certas representações da mulher e do sexo que despontam entre os últimos românticos e ganham corpo com os "primeiros baudelairianos" no Brasil, fazendo convergir erotismo extremado (com notações perversas de sadismo e canibalismo amoroso) e alegoria política, na medida em que podem tomar o ato amoroso como síntese dos ideais liberais e republicanos. Palavras-chave: poesia romântica, poesia realista, alegoria política, imagens femininas, primeiros baudelairianos
\end{abstract}

Résumé: Cette intervention a pour objet l'examen de certaines représentations de la femme et du sexe, émergeant parmi les derniers romantiques avant de gagner corps avec les "premiers baudelairiens" du Brésil, en faisant converger l'érotisme extrême (incluant les ressources perverses du sadisme et du cannibalisme amoureux) et l'allégorie politique, dans la mesure où ils considèrent l'acte amoureux comme une synthèse des idéaux libéraux et républicains.

Abstract: The present essay intends to examine certain representations of the woman and sex that surface among the later Romantics and that incarnate in the "early Baudelairians" in Brazil, in a concurrence of extreme eroticism (with perverse notations of loving sadism and cannibalism) and political allegory, as long as they may take the love act as a synthesis of liberal and republican ideals.

Keywords: Romantic poetry, realist poetry, political allegory, feminine images, first Baudelairians 
O presente ensaio tem por objetivo examinar certas representações da mulher e do sexo que despontam entre os últimos românticos e ganham corpo, efetivamente, com os primeiros baudelairianos no Brasil, fazendo convergir erotismo extremado e política, na medida em que podem tomar o ato amoroso como síntese de ideais liberais ou republicanos.

Começo lembrando a observação de Antonio Candido a propósito dos baudelairianos dos anos 1870 a 1880, que teriam promovido certa deformação salutar da obra do poeta francês, cuja presença se faz sentir na poesia deles sobretudo pela sexualidade acentuada. Esse traço demasiadamente $c r u$ das apropriações dos ditos realistas foi duramente criticado por Machado de Assis em "A nova geração", que inclusive lembrava o horror de Baudelaire ao rótulo de realista - "cette grossière épithète". Como observa Candido, embora Machado de Assis tivesse "formalmente razão", em perspectiva histórica, os primeiros baudelairianos estavam certos em deformar

segundo as suas necessidades expressivas, escolhendo os elementos mais adequados à renovação que [...] de fato promoveram. Esses elementos (o "descompassado amor à carne" e o "satanismo") representavam atitudes de rebeldia, [ao fazer] do sexo uma plataforma de libertação e combate, que se articulava à negação das instituições. Eles eram agressivamente eróticos, com a mesma truculência com que eram republicanos e agrediam o Imperador, chegando até o limiar do socialismo. Portanto, foi um grande instrumento libertador esse Baudelaire unilateral ou deformado, visto por um pedaço, que fornecia descrições arrojadas da vida amorosa e favorecia uma atitude de oposição aos valores tradicionais, por meio de dissolventes como o tédio, a irreverência e a amargura. ${ }^{2}$

Sempre de acordo com Candido, o ponto de apoio dessa atitude foi a luta contra o romantismo declinante em prol do realismo poético ou social, que defendia uma poesia progressista em política, inspirada em Les Châtiments, de Hugo, e desmistificadora em relação à vida afetiva, nisso recorrendo a Baudelaire, com o reforço mediador decisivo dos portugueses da "geração de 65" (Antero de Quental, Guerra Junqueiro e Gomes Leal), que já tinham enfeixado ambos os poetas franceses em suas obras.

1. Apud machado de Assis, J. M. "A nova geração". Crítica literária. Obras completas. Rio de Janeiro, São Paulo e Porto Alegre: W. M. Jackson, 1938.

2. CANDIDO, Antonio. “Os primeiros baudelairianos no Brasil”. In: A educação pela noite e outros ensaios. São Paulo: Ática, 1987, pp. 23-38. 
A poesia de Carvalho Júnior "dá o tom” ao realismo poético brasileiro, cujo soneto "Profissão de fé", em franco diálogo com "LIdéal" de Les Fleurs du mal, vale por manifesto antirromântico:

PROFISSÃO DE FÉ

Odeio as virgens pálidas, cloróticas, Beleza de missal que o romantismo Hidrófobo apregoa em peças góticas, Escritas nuns acessos de histerismo.

Sofismas de mulher, ilusões óticas, Raquíticos abortos de lirismo, Sonhos de carne, compleições exóticas, Desfazem-se perante o realismo.

Não servem-me esses vagos ideais Da fina transparência dos cristais, Almas de santa e corpo de alfenim.

Prefiro a exuberância dos contornos, As belezas da forma, seus adornos, A saúde, a matéria, a vida enfim.

A conotação patológica do original baudelairiano é aqui mantida, inclusive empregando o mesmo termo médico, "clorose", mas acaba sendo exagerada pelo acúmulo de outros tantas expressões mórbidas ("aborto raquítico", "acessos de histerismo", "hidrófobo"...) que qualificam explicitamente o romantismo como o alvo do ataque, o que em Baudelaire não é identificado. No autor de Les Fleurs du mal, nota também Candido, a rejeição da mulher descarnada pela idealização se dá de maneira mais contida ou neutra, como mera constatação ("Ce ne seront jamais ces beautés de vignettes [...] qui sauront satisfaire un coeur comme le mien"), sem o ódio explícito de Carvalho Júnior. Em "LIdéal”, tal modelo de beleza conta com uma referência plástica ou gráfica: são "beautés de vignettes", que em Carvalho Júnior passam a ser "belezas de missal" - conotação religiosa importante quando se considera com Glória Carneiro 
do Amaral ${ }^{3}$ o realismo agnóstico que dominava essa geração. Tanto Candido quanto Amaral concluem suas análises dessa declaração dos princípios poéticos constatando que, enquanto Baudelaire encerra seus versos contra as belezas cloróticas remetendo a um ideal de beleza verdadeiramente titânico, com a evocação de modelos da Antiguidade e da Renascença (como Ésquilo e Michelangelo), Carvalho Júnior se concentra na mulher de todo dia, restaurada em sua integridade carnal, que melhor lhe convinha para opor às virgens etéreas dos sonhos dos românticos.

É preciso observar que, em termos de tradição romântica local, o alvo da investida de Carvalho Júnior e sua geração foi a diluição, por parte dos epígonos, dos ideais amorosos e de certos modelos femininos postos em circulação por Álvares de Azevedo, que concebe, platonicamente, a mulher como encarnação do eterno feminino (Goethe), representação sensível de uma abstração (o ideal de poesia). ${ }^{4}$ É característica dessa representação ideal a figura da bela adormecida (explicitamente tematizada em "Cantiga", na Lira dos vinte anos), contemplada no leito, entregue ao sono e aos sonhos, enquanto o eu lírico constrói seu discurso poético idealizador, sem encenar qualquer gesto ou, no máximo, arriscando um beijo colhido a furto. Poemas emblemáticos dessa atitude são os que se iniciam com os versos "Pálida, à luz da lâmpada sombria" e "Quando à noite no leito perfumado",

PÁLIDA, À LUZ DA LÂMPADA SOMBRIA,

Sobre o leito de flores reclinada,

Como a lua por noite embalsamada,

Entre as nuvens do amor ela dormia!

Era a virgem do mar, na escuma fria

Pela maré das águas embalada!

Era um anjo entre nuvens d'alvorada

Que em sonhos se banhava e se esquecia!

3. Amaral, Glória Carneiro do. Aclimatando Baudelaire. São Paulo: Annablume, 1996.

4. CunHA, Cilaine Alves. O belo e o disforme. São Paulo: Edusp, 1997. 
Era mais bela! o seio palpitando...

Negros olhos as pálpebras abrindo...

Formas nuas no leito resvalando...

Não te rias de mim, meu anjo lindo!

Por ti - as noites eu velei chorando,

Por ti - nos sonhos morrerei sorrindo!

“Dreams! dreams! Dreams!', W. Cowper

QUANDO À NOITE NO LEITO PERFUMADO

Lânguida fronte no sonhar reclinas,

No vapor da ilusão por que te orvalha

Pranto de amor as pálpebras divinas?

E, quando eu te contemplo adormecida

Solto o cabelo no suave leito,

Por que um suspiro tépido ressona

E desmaia suavíssimo em teu peito?

Virgem do meu amor, o beijo a furto

Que pouso em tua face adormecida

Não te lembra no peito os meus amores

$\mathrm{E}$ a febre de sonhar da minha vida?

Dorme, ó anjo de amor! no teu silêncio

$\mathrm{O}$ meu peito se afoga de ternura

E sinto que o porvir não vale um beijo

E o céu um teu suspiro de ventura! 
Um beijo divinal que acende as veias,

Que de encantos os olhos ilumina,

Colhido a medo como flor da noite

Do teu lábio na rosa purpurina,

E um volver de teus olhos transparentes,

Um olhar dessa pálpebra sombria,

Talvez pudessem reviver-me n’alma

As santas ilusões de que eu vivia!

Esses e outros poemas do autor da Lira dos vinte anos foram apropriados ${ }^{6}$ por mais de um baudelairiano, dentre os quais Teófilo Dias, autor de um livro de estreia ainda romântico, intitulado bem ao gosto azevediano de Lira dos verdes anos (1878), que repõe de modo evidente essa situação paradigmática em poemas desse livro como "O sono" ou em "O leito" e "Miniatura", incluídos em Fanfarras (1882). Aliás, a leitura desses poemas na sequência indicada é bastante ilustrativa da transfiguração radical da referida cena paradigmática, operada na transição do romantismo para o realismo poético e nutrida pela leitura de Baudelaire.

Assim, no primeiro dos três poemas (quase paráfrase de "Quando à noite no leito perfumado..." desde a epígrafe de Cowper, também emprestada a esse poema de Álvares de Azevedo), a figura feminina aparece ainda como imagem pudica, casta, já que evocada, bem ao gosto romântico, como "anjo dos sonhos meus", cujo respirar é comparado ao "brando ofegar de uma criança" e que revela "sisuda a fronte perfumada e pura", enquanto "dorme tranquila", "sozinha,/ da inocência no cândido abandono", com o rosto palidamente iluminado pelos raios do luar... Diante da bela adormecida, o eu lírico, penando "na febre da agonia", adota a atitude, tipicamente azevediana, de contemplação ou mesmo de adoração, postado de joelho aos pés da moça, ansiando por ouvi-la murmurar o nome dele em sonho e implorando para que ela "não descerre a pálpebra sombria"?

5. Álvares de azevedo, M. A. Poesias completas (org. Péricles E. da Silva Ramos). Campinas: Edunicamp, 2002.

6. Candido chega a falar em verdadeiros pastiches de Álvares de Azevedo entre outros românticos (o tio Gonçalves Dias, Casemiro de Abreu, Fagundes Varela...). Ver a introdução e as notas do crítico a dias, Teófilo. Poesias escolhidas. São Paulo: Conselho Estadual de Cultura. 1960.

7. DIAS, Theophilo. Lyra dos verdes anos. Rio de Janeiro: Evaristo Rodrigues da Costa, 1878, pp. 22-23. 
Já em "O leito", incluído na seção de Fanfarras intitulada "Flores Funestas" - que com seus dezenove poemas compõe "o maior conjunto de poemas produzidos sob a influência de Baudelaire na literatura brasileira do século XIX" ${ }^{-}$-, a cena paradigmática da alcova e da mulher lânguida adormecida no leito é eroticamente transfigurada pela inspiração colhida em parte na leitura de "Le Chevalure", de cujos versos Teófilo Dias empresta não só o ritmo e o esquema rímico das quintilhas ( $a b a a b$ ), mas também algo das imagens, como bem demonstrou Amaral. ${ }^{9}$ As analogias ou metáforas marítimas com que o poeta francês descreve a "crinière lourde" da amada, comparada à "mer d'ébène" ou ao "noir océan, em que o eu baudelairiano "plongerai [sa] tête amoureuse d'ivresse", são deslocadas por Dias para os lençóis do leito da amada:

Mares de espúmeo arbor de rendas revestidos

Vagas, cheias de aroma, e de torpor fecundas!

Para a febre lenir, que esvaira-me os sentidos,

Quero nestes lençóis mergulhá-los, vencidos,

Num mar de sensações letárgicas, profundas!"10

O elemento tipicamente baudelairiano do filtro inebriante ou tóxico - que em outros poemas também aparece associado ao gosto, ao cheiro ou a voz da mulher amada ${ }^{11}-$ impregna os lençóis e, mais adiante, "embebe a alcova, em toda plenitude", como

8. Amaral, Glória Carneiro do. Op. cit., p. 121.

9. Péricles Eugênio da Silva Ramos é quem chamou a atenção para o tom do esquema rímico das quintilhas inspiradas em "Le chevalure", ao passo que Amaral (op. cit., pp. 126 ss) deu destaque para as demais afinidades. De Ramos, ver "A renovação parnasiana na poesia”. In coutinho, A. (Org.). A literatura no Brasil. Rio de Janeiro: Ed. Sul Americana, 1969. v. 3, pp. 83-134.

10. DIAs, Theophilo. Fanfarras. São Paulo: Ed. Dolivaes Nunes, 1882, pp. 24-25.

11. Foi Candido quem primeiro chamou a atenção para a incorporação desse elemento baudelairiano do filtro tóxico e inebriante na introdução à referida edição de Poemas escolhidos. Amaral desdobraria a análise dessa incorporação ao lado de outras imagens e analogias tipicamente baudelairianas presentes em Dias e outros contemporâneos, como a eletricidade felina da mulher, seus "cheveux élastiques et lourds", assim como as metáforas animais associadas aos instintos, que têm em "A matilha" a sua realização talvez mais feliz nessa geração (op. cit., p. 148). 
A emanação sutil, que enleva, que extasia,

De um corpo virginal e cheia de saúde,

Grato eflúvio do sangue, em plena juventude,

Que do olfato a avidez satura, e não sacia.

Pelo perfume, portanto, se alude à representação mais física e natural (ou naturalista) da mulher amada, rompendo com a imagem sublimada e romântica ainda presente no poema anterior. Assim também a atitude contida do eu lírico, apesar da febre da agonia de "O sono", cede a vez a "vagos pensamentos" suscitados por esse perfume que lhe retesa os nervos e o conduz ao êxtase.

Por último, a intensificação tanto maior do erotismo na composição da cena paradigmática ocorre nas mesmas "Flores funestas" com "Miniatura", que se abre e fecha num jogo marcante de sombra e luz: a "placidez sombria" ou a "penumbra discreta" da alcova em que se instala a amada e a luz do sol que, no "fulgido esplendor do meio-dia", de modo viril, "por uma tênue fenda, estreita, esguia,/ dardeja uma áurea seta”... Esse sol que ilumina a cena lírica responde pelo calor que faz o corpo da amada figurar "prostrado, frouxo, lânguido, abatido.... O "torpor sonolento" contribui significativamente para o erotismo da imagem do corpo feminino que deslumbra e fascina, imerso num "silêncio calmoso" que "enche da alcova o tépido ambiente,/ pérfido e carinhoso". Corpo esse figurado através das "transparências vagas do tecido das rendas da cortina", em meio ao "imóvel cortinado,/ emoldurando um leito sedutor,/ atraente, fatal, como um pecado...." Em nota algo profanatória, essa visão é associada à imagem da "madona,/ no seu marmóreo nicho rendilhado". O poema parece quase se aproximar de uma lógica determinista entre a ação desse calor tropical e o erotismo exacerbado da cena, notadamente no momento em que o eu se refere ao rosto suado da moça, devido ao calor intenso, estabelecendo uma analogia sugestiva: a "tenra, nívea tez,/ tão úmida e macia, que parece/ um fruto do Equador,/ que deixa ressumar, se o sol o aquece,/ na polpa externa o rórido calor". ${ }^{13}$ Não se chega, todavia, no poema àquela ação implacável do meio, que seria logo depois explorada de forma determinante no romance naturalista.

É importante observar que a situação paradigmática já tinha sido retomada e, até certo ponto, subvertida no final do próprio romantismo por um Castro Alves, não só em "Adormecida", como também na recriação da famosa cena da alba de Romeu e Julieta em:

12. Id., pp. 32-33.

13. Id., p. 34 . 
BOA-NOITE

Veux-tu donc partir? Le jour est encore éloigné:

Cétait le rossignol et non pas l'alouette,

Dont le chant a frappé ton oreille inquiète;

Il chante la nuit sur les branches de ce granadier

Crois-moi, cher ami, cétait le rossignol.

Shakespeare

Boa noite, Maria! Eu vou-me embora.

A lua nas janelas bate em cheio...

Boa noite, Maria! É tarde... é tarde...

Não me apertes assim contra teu seio.

Boa noite!... E tu dizes - Boa noite.

Mas não digas assim por entre beijos...

Mas não mo digas descobrindo o peito,

- Mar de amor onde vagam meus desejos.

Julieta do céu! Ouve... a calhandra

Já rumoreja o canto da matina.

Tu dizes que eu menti?... pois foi mentira...

...Quem cantou foi teu hálito, divina!

Se a estrela-d'alva os derradeiros raios

Derrama nos jardins do Capuleto,

Eu direi, me esquecendo d'alvorada:

"É noite ainda em teu cabelo preto..."

É noite ainda! Brilha na cambraia

- Desmanchado o roupão, a espádua nua -

o globo de teu peito entre os arminhos

Como entre as névoas se balouça a lua... 
É noite, pois! Durmamos, Julieta!

Recende a alcova ao trescalar das flores.

Fechemos sobre nós estas cortinas...

- São as asas do arcanjo dos amores.

A frouxa luz da alabastrina lâmpada

Lambe voluptuosa os teus contornos...

Oh! Deixa-me aquecer teus pés divinos

Ao doido afago de meus lábios mornos.

Mulher do meu amor! Quando aos meus beijos

Treme tua alma, como a lira ao vento,

Das teclas de teu seio que harmonias,

Que escalas de suspiros, bebo atento!

Ai! Canta a cavatina do delírio,

Ri, suspira, soluça, anseia e chora...

Marion! Marion!... É noite ainda.

Que importa os raios de uma nova aurora?!...

Como um negro e sombrio firmamento,

Sobre mim desenrola teu cabelo...

E deixa-me dormir balbuciando:

- Boa noite! -, formosa Consuelo... ${ }^{14}$

Nesse poema, o eu lírico abandona a atitude contemplativa, retornando ao leito da e com a amada a fim de realizar plenamente a vivência amorosa, unindo corpo e espírito, numa erotização projetada por todo o cenário, a começar pela luz da lâmpada: de "sombria", em Álvares de Azevedo (conferindo uma palidez de morte à amada reclinada num leito de flores), à "frouxa luz da alabastrina lâmpada", como a reverberar o desejo ou impulso do amante, "lambe voluptuosa" os "contornos" da amada... Há, além disso, o agenciamento das metáforas musicais orquestrando os suspiros ou gemidos dos

14. Castro alves, Antonio de. Espumas flutuantes/Os escravos. São Paulo: Martins Fontes, 2001. 
amantes, desde as preliminares até o ápice do gozo amoroso (a "cavatina do delírio"). A mulher amada (mera e simples Maria) é equiparada a grandes representações femininas imortalizadas pela literatura, da Julieta shakespeariana à Consuelo de George Sand e à Marion, que tanto pode ser a de Hugo, quanto a de Musset - valendo notar que, em ambos os casos, a equiparação a uma cortesã ou prostituta não compromete a imagem da amada, dado o grau de idealização romântica. Mas o fato é que, embora tenha rompido, assim, com a imagem abstratizante e platônica da mulher e do amor azevedianos, Castro Alves reveste ainda a experiência amorosa de uma aura de idealidade, equilibrando as duas dimensões do amor, a física e a espiritual.

É só na geração ou escola seguinte que esse equilíbrio entre a dimensão física e a transcendente, entre a idealidade e a materialidade, tenderá a se romper ou desestabilizar pela ênfase na experiência mais carnal do amor ou pela hipertrofia da componente erótica, como ainda diz Candido. Veja-se, nesse sentido, a retomada da cena paradigmática dos românticos - a mulher adormecida no leito, imersa num sono ambíguo aparentado à morte - por Carvalho Júnior em "Adormecida", que propositadamente evoca, já no título, os poemas de Álvares de Azevedo, bem como outro poema homônimo de Castro Alves em Espumas flutuantes. Mas essa retomada vem marcada por uma contradição e por certo artificialismo denunciados por Amaral, na medida em que o eu lírico, embora fale, nas primeiras estrofes, na aparência mórbida do corpo adormecido típica dos românticos, acaba por descrever um corpo fresco, rosado e agitado pela efervescência do sangue, que deveria rechaçar e não excitar os instintos masculinos, comparados a abutres esfaimados, numa espécie de "necrofilia latente". ${ }^{15}$ Creio, entretanto que essa contradição efetiva do poema é produto da transição de uma estética à outra.

Valeria, ainda, contrastar a representação da cena do despertar dos amantes em "Boa noite", que repõe a convenção própria da alba shakespeariana, com a mesma cena em

APRÈS LE COMBAT

Quando, pela manhã, contemplo-te abatida, Amortecido o olhar e a face descorada, Imersa em languidez profunda, indefinida, O lábio ressequido e a pálpebra azulada,

15. AMARAL, op. cit. 
Relembro as impressões da noite consumida

Na lúbrica expansão, na febre alucinada

Do gozo sensual, frenético, homicida,

Como a lâmina aguda e fria de uma espada.

E ao ver em derredor o grande desalinho

Das roupas pelo chão, dos móveis no caminho,

E o boudoir enfim do caos - fiel plágio,

Suponho-me um herói da velha antiguidade,

Um marinheiro audaz após a tempestade,

Tendo por pedestal os restos dum naufrágio! ${ }^{16}$

A divergência já se evidencia na maneira como Carvalho Júnior retoma as metáforas marciais, recorrentes desde a tradição clássica, para descrever o ato sexual, a começar pelo título meio eufemístico, seguindo com as descrições da referida "luta" em termos de "perda da razão, febre alucinada, frenética e homicida" para concluir com "o caos e o naufrágio". Como nota Amaral, a imagem fálica das armas de luta e outras metáforas audazes, dos instintos sexuais masculinos, justificariam a qualificação de priapesca com que Machado define a poesia de Carvalho Júnior.

Outro aspecto que se costuma destacar na apropriação muito particular do erotismo baudelairiano pela geração de Carvalho Júnior é a animalização dos instintos, já presente nos mesmos versos de "Adormecida", mas de modo algum em As flores do mal. Essa animalização, nota ainda Amaral, faz com que o amor carnal passe, metaforicamente, a carnívoro, no poema de Carvalho Júnior intitulado, justamente, "Antropofagia", manifestando de modo distinto o sadismo que o grande poeta francês introduziu na lírica moderna: ${ }^{17}$

16. Apud. amaral, op. cit. Todos os poemas de Carvalho Júnior foram aqui reproduzidos de acordo com a transcrição da ensaísta.

17. Ver comentário do poema em AMARAL, op. cit. pp. 91-93. É importante destacar que o sadismo legado pela lírica baudelairiana encontra nessa geração sua grande expressão em um dos mais belos poemas de Fontoura Xavier, "Pomo do mal", que foi objeto de uma análise magistral de Antonio Candido no ensaio homônimo. Ver: O discurso e a cidade. São Paulo: Duas Cidades, 1993, pp. 245-256. 
Mulher! ao ver-te nua, as formas opulentas

Indecisas luzindo à noite, sobre o leito,

Como um bando voraz de lúbricas jumentas,

Instintos canibais refervem-me no peito.

Como a besta feroz a dilatar as ventas

Mede por dar-lhe o bote ajeito,

Do meu fúlgido olhar às chispas odientas

Envolvo-te, e, convulso, ao seio meu t'estreito:

E ao longo de teu corpo elástico, onduloso,

Corpo de cascavel, elétrico, escamoso,

Em toda essa extensão pululam meus desejos,

- Os átomos sutis, - os vermes sensuais,

- Cevando a seu talante as fomes bestiais

- Nessas carnes febris, - esplêndidos sobejos!

Depois da grande subversão da tópica romântica promovida pelos primeiros baudelairianos, a cena paradigmática da mulher contemplada no leito volta a reaparecer em um dos grandes parnasianos brasileiros (não por acaso, o mais romântico deles), mas sem a ambivalência com que foi forjada por Álvares de Azevedo na lírica brasileira:

PRIMEIRAS VIGÍLIAS

Dos revoltos lençóis sobre o deserto

Despejava-se, em ondas silenciosas,

O luar dessas noites vaporosas,

De seu lânguido cálix todo aberto.

Rangia a cama, e desusavam perto

Alvas, femíneas formas ondulosas;

E eu a idear, nas ânsias amorosas,

Seus ombros nus, seu colo descoberto. 
E a gemer : - "Abeirai-vos de meu leito,

Ó sensuais visões da adolescência,

E abrasai-vos na pira em que me inflamo!

Fervem paixões despertas no meu peito;

Descai a flor virgínea da inocência,

E irrompe o fruto dolorido... Eu amo !"18

Aqui, as fantasias são claramente identificadas como sendo da adolescência, associando assim intimamente o tipo de representação amorosa da mulher no leito com o mito do eu adolescente que Álvares de Azevedo criou poeticamente. ${ }^{19} \mathrm{Em}$ Correia, porém, há uma dose de erotismo muito mais intensa, embora sem chegar às representações violentas, sádicas e perversas dos primeiros baudelairianos, ainda que possa ter-se beneficiado das conquistas eróticas destes.

II

Se a algolagnia parece figurar, predominantemente, como uma prerrogativa da sexualidade masculina, teremos também nessa geração de baudelairianos, em menor grau, a situação inversa, em que a mulher deixa de ser objeto inerte de posse e realização dos impulsos sexuais do homem para se converter em agente da sedução. A inversão de papeis, está visto, tem a ver com uma tendência característica na passagem da literatura romântica para as escolas pós-românticas.

Mario Praz demonstrou como, em fins do século xviII e durante a primeira metade do XIX, predominou a figura do homem fatal, cujo retrato mais acabado corresponderia ao mito byroniano concebido sob a insígnia do divino marquês (de Sade) e incorporando alguns traços tomados do Satã de Milton. Já a literatura e a pintura

18. CORREIA, Raimundo. Alleluias. Rio de Janeiro: Cia Editora Fluminense, 1891, pp.165-66.

19. Busquei examinar a construção literária (contrariando as teses de fundo biografizante) desse mito da adolescência na obra azevediana em: CAmiLo, Vagner. "Álvares de Azevedo, o Fausto e o mito romântico do adolescente no contexto político-estudantil do Segundo Reinado". Itinerários, Araraquara, n. 33, pp. 63-108, jul.-dez. 2011.

66. CAMILO, Vagner. Erotismo e lírica: figurações femininas 
da segunda metade do século XIX chegando ao fin de siècle, grosso modo, inverteriam as posições, projetando o homem fatal para segundo plano e trazendo para o centro da cena a femme fatale, seja nas versões míticas (a Esfinge, Helena de Troia, Cleópatra, Herodíade ou, entre outras, a irmandade castradora bíblica: Salomé, Judite e Dalila...), seja nas criações privadas ou pessoais (a exemplo de La belle dame sans merci de Keats). ${ }^{20}$ Todas elas encarnam os atributos essenciais que definem o tipo, como a função de chama que atrai e queima, a inacessibilidade física e o prazer perverso com o sofrimento causado aos apaixonados. Além disso, essa imagem de mulher sedutora tende, com frequência, a ser associada a terras ou países distantes tidos como exóticos. Como bem nota Praz, aliado ao erotismo, esse exotismo é claramente "uma projeção fantástica de uma carência sexual" que materializa a inacessibilidade feminina em termos de distância espacial, geográfica. ${ }^{21}$

Examinando a reincidência desse tipo feminino em Valle Inclán, inspirado por poetas anteriores, como o nicaraguense Ruben Dario (que, vale lembrar, foi interlocutor e intérprete de um dos primeiros baudelairianos no Brasil: Fontoura Xavier), Lily Litvak observa o seguinte, a respeito da subversão promovida por tal figura dominadora em relação ao tipo feminino que marcou a história da lírica desde pelo menos a Beatriz de Dante, passando por toda a tradição petrarquista (do qual Camões é tributário) e chegando a suas reedições neoplatonizantes do romantismo:

O mito do eterno feminino se unia irremissivelmente à maldade. $\mathrm{O}$ fim do século se submeteu à fascinação de grandes cortesãs, cruéis rainhas ou famosas pecadoras. ${ }^{22}$

Peter Gay retomaria essa representação feminina a fim de alegar uma motivação psicossocial, digamos assim, para a recorrência do tipo da mulher devoradora na produção artístico-literária do período: sem se resumir, como se chegou a supor, a uma reação simbólica à campanha feminista em seus albores (reação essa movida por um imaginário masculino ameaçado em sua supremacia), a moda da mulher fatal advinha, em parte, dos conflitos resultantes de

20. PRAZ, Mario. A carne, a morte e o diabo na literatura romântica. Tradução de Philadelpho Menezes. Campinas: Ed. Unicamp, 1996.

21. Id., p. 172.

22. LITVAK, Lily. "La mujer fatal”. Erotismo fin de siglo. Barcelona: Antoni Bosch Ed., 1979, p. 145. 
uma cultura rígida na defesa de posições tradicionais - os burgueses do século XIX confirmaram a frase freudiana de que ninguém gosta de abrir mão de um prazer que já teve. Mas também era uma cultura mais flexível que suas antecessoras; a promessa de novos prazeres incitava a correr riscos. O curso tortuoso e o triunfo último do movimento das mulheres demonstram a capacidade que muitos burgueses tinham e têm de reformular suas defesas culturais e rever seus ideais sociais. Homens influentes acabaram percebendo que o anjo do lar não era um anjo nem era preciso ficar confinado em casa. Ao mesmo tempo, o acúmulo de quadros, poemas e romances sobre mulheres predadoras atesta a capacidade que tinha a cultura liberal de sondar questões delicadas e difíceis que abordavam, de modo até certo ponto explícito, alguns dos segredos mais ciosamente guardados da sexualidade masculina. Poucos daqueles que se entregavam em público ao sofrimento provocado pelas mulheres perigosas eram censurados, quanto mais criticados, por exporem suas cicatrizes ou suas feridas. A cultura liberal do século XIX era bem provida de ansiedade, mas estava ao mesmo tempo suficientemente madura e preocupada para permitir que suas ansiedades chegassem ao conhecimento público. ${ }^{23}$

Isso posto, podemos traçar algo de uma genealogia dessa figuração da mulher fatal na poesia brasileira, emergindo ainda no bojo do romantismo com "Lélia" de Álvares de Azevedo e seguindo com o Castro Alves de "O tonel das Danaides" e outros hugoanos da terceira geração, antes de eclodir em figurações múltiplas com os primeiros baudelairianos (a exemplo de "Nêmesis", de Carvalho Júnior, ou "A Esfinge", "A voz" e "Latet anguis", de Teófilo Dias) e com os parnasianos, tal como a "Guerreira" nas Panóplias de Olavo Bilac. Isso sem falar em certas aparições vanguardistas (ou mais especificamente surrealistas) desse tipo feminino em Drummond (com "O mito", por exemplo, de A rosa do povo), Murilo Mendes (com "Alegoria”, de Sonetos brancos) e outros modernistas.

Com os primeiros baudelairianos, ela chegará a assumir, inclusive, outra dimensão ainda não evidenciada pela crítica: sua construção como alegoria. Nisso também seguiam de perto o autor das Flores do mal, no poema justamente intitulado "Allégorie", que repõe a figura da femme fatale concebida nos termos indicados pelo título. Destacam-se, nela, os atributos mencionados por Praz, ao lado de outros: a beleza como dom sublime; a opulência e a "rude majestade"; a esterilidade da "vierge

23. GAY, Peter. A paixão terna - a experiência burguesa: da rainha Vitória a Freud. Tradução de Sergio Flaksman. São Paulo: Companhia das Letras, 1990, p. 359. 
inféconde"; o temor que inspira; o modo como tudo desfalece e morre a seu simples toque; o poder de extrair "o perdão de todo crime infame"; sua indiferença em relação a toda ameaça, ao Purgatório e ao Inferno; o desprezo e a ironia diante da morte; o andar majestoso e os traços orientalistas na forma de repousar de uma sultana, além da crença maometana que ela deposita no prazer... Nessa referência, mais do que a associação feita por Praz entre orientalismo e exotismo como projeção espacial da inacessibilidade feminina, talvez se possa pensar em algo próximo ao "despotismo oriental" de que tratou Ross Chambers ao examinar a "violência poética ou simbólica" 24 encenada na dedicatória "Ao leitor" hipócrita de As flores do mal. Ele chama a atenção para a personagem que aparece fumando calmamente seu houka, tendo uma lágrima fortuita no olho e, ao mesmo tempo, sonhos de cadafalso. Chambers vê nessa figura do déspota oriental (lido com base nas considerações de Marx sobre o "modo de produção asiático") a encarnação simbólica da própria burguesia em seu momento inicial de afirmar a dominação à custa da violência e opressão extremas praticadas em junho de 1848. Mais especificamente, esse despotismo oriental é uma metáfora, no poema, para a hipocrisia, o Ennui ou o estado de torpor, vazio ou indiferença com que a burguesia buscou reprimir a consciência dos horrores praticados nas barricadas e os temores de revanche operária.

Trata-se, sem dúvida, de um resumo bastante simplificado e mecânico, embora não se possa esquecer que a alegoria sempre foi aparentada ao esquematismo... Seja como for, essas considerações ajudam a compreender os vínculos entre erotismo e política, entre o corpo feminino e o corpo social, por meio da alegoria, que também vigorou, ainda que com muito menos frequência, em algumas das representações femininas de nossos primeiros baudelairianos, guardadas, é claro, as especificidades político-sociais do contexto histórico brasileiro.

$\mathrm{Na}$ verdade, antes mesmo deles, a figura da femme fatale como alegoria especialmente política já comparecia entre os últimos românticos, com um hugoano hoje esquecido: Pedro Luís. ${ }^{25}$ É o que se vê nos versos de "Terribilis Dea".

24. Chambers, Ross. Mélancolie et opposition: les débuts du Modernisme en France. Paris: José Corti, 1987.

25. Apesar de hoje esquecido, Pedro Luís marcou época, com "meia dúzia de peças altissonantes, de vibração patriótica e política”. Candido lembra, a esse respeito, as palavras do prefaciador de Poesias de Pedro Luís, quando se refere ao aparecimento deste no seio da geração que sucedeu à de Álvares 
$\mathrm{Na}$ abertura do poema, a inesperada aparição dessa terrível deusa, figura resplandecente e sanguinária, com o rubro pavilhão ao vento, cuja identidade se desconhece, é capaz de arrebatar freneticamente toda uma nação:

Quando ela apareceu no escuro do horizonte,

O cabelo revolto... a palidez na fronte...

Aos ventos sacudindo o rubro pavilhão,

Resplendente de sol, de sangue fumegante,

O raio iluminou a terra... nesse instante

Frenética e viril ergueu-se uma nação!

Quem era? De onde vinha aquela grande imagem,

Que turbara do céu a límpida miragem,

E de luto cobrira a senda do porvir?

De que abismo saiu?... do túmulo? do inferno?

Pode o anjo do mal desafiar o Eterno?

Da fria sepultura o espectro ressurgir?

As estrofes seguintes tratam de enumerar demais atributos ameaçadores dessa "grande divindade", mulher fantasma e visão dantesca, cujo peito largo é inflado pelo sopro das paixões e cujo culto é a mortandade. Ela é "dos campos de batalha a hórrida bacante,/ que mergulha no sangue e ri das maldições!”. Outros tantos epítetos são empregados no sentido de tornar ainda mais demoníaca e sinistra essa "deusa sepulcral" que celebra "no sangue as grandes saturnais". Impávida no andar e trajada de gala e luto, ela é rodeada por uma "lúgubre coorte", "o séquito da morte,/ a miséria que chora, a glória que seduz". Essa deusa fatal que nasceu junto com o mal e vive através dos séculos

Levanta o gládio nu em nome da verdade,

Acorda em fúria acesa à voz da liberdade...

E no punho viril derrete-lhe o grilhão!

de Azevedo, assinalando que sua glória consistiu em quebrar a "monotonia daqueles cantos tristes com os canglores do seu clarim de guerreiro" (apud CANDido, Antonio. "Novas direções na poesia". In: Formação da literatura brasileira: momentos decisivos. Belo Horizonte: Itatiaia, 1981, v. 2, p. 252). Ver ainda: NEME, Mário. "Pedro Luís. Notas para uma biografia". RAM. São Paulo, 1940. 
Como é bela! ... Depois... sem fé, sem heroísmo,

Despedaça a justiça e atira com cinismo

A virgem liberdade aos braços da opressão!

Ao fim e ao cabo, sabemos que essa mulher devassa alegoriza a própria guerra, suas motivações e consequências. Mas se o poeta enumera os diversos momentos da história em que ela esteve presente, ao lado de Átila, Cipião, César, Pompeu, Rolando, Carlos, o grande ou Napoleão, entre outros tantos, não é para encerrá-la, descontextualizada, numa abstração. Sua evocação por Pedro Luís tem em mira um momento histórico muito precisamente circunscrito, como se vê na décima quarta estrofe:

Ela estava também - espectro pavoroso -

Do Amazonas a bordo, ao lado de Barroso,

De pólvora cercada, em pé, sobre o convés...

Quando, à voz do valente, o monstro foi bufando,

Calados os canhões, navios esmagando,

A deusa varonil de amor caiu-lhe aos pés!

Os versos são marcados por certa ambiguidade, na medida em que, por um lado, qualificam a "deusa varonil", "deusa da guerra", "arcanjo da batalha" como "espectro pavoroso", que "arrancas do bronze os cânticos malditos", enquanto "ferve e corre o sangue em quentes borbotões". Mas o eu lírico, por outro lado, apesar dos horrores que ela preside, não deixa de saudar essa que nos dera "o sonho da vingança,/ o gládio da justiça [,] o raio da esperança,/ e da glória cruenta o mágico esplendor!". Pode-se entender esse louvor como ironia, quando, ainda nos últimos versos, a respeito da natureza do som com que a deusa é louvada, o eu poético diz:

É para te saudar que brame a artilharia,

E que repete ao longe a voz da ventania

Das trombetas da morte o hórrido clangor!

A ambiguidade, todavia, cai por terra quando se lembra que, em dois outros poemas recolhidos nos seus Dispersos, Pedro Luís não deixa dúvida com relação à sua visão da guerra, saindo em defesa incondicional do Brasil em detrimento do Paraguai. Em "Hino de guerra", movido pelo desejo de vingança pátria, dirá que "Arda em chamas o 
vil Paraguai/ Pela pátria! Por Deus! pelo mundo". ${ }^{26}$ A Solano Lopez irá se referir, mais adiante nos versos, como covarde e monstro, acusação enfatizada no poema justamente intitulado "Covarde!..., que concentra sua investida estritamente naquele que o poeta denomina de déspota, "tirano do Paraguai" ou fera, "abutre/ que a carniça jamais fartou”. Constrói ainda a imagem do país vizinho como fétido, sinistro e funéreo, sob o "império da crueldade", onde a virtude e a razão foram proscritas e a que falta por completo a "luz divina”... ${ }^{27}$ Nesses poemas, portanto, Pedro Luís não se afasta das alegações e justificativas oficiais dadas então à Guerra do Paraguai.

Dessa guerra vista como prova de patriotismo ou nacionalismo, somada a alegadas razões (todas de cunho personalista) de combate à ambição desmedida, à política fraudulenta e ao caráter ditatorial, autoritário do caudilho paraguaio Solano López, são conhecidos os custos finais dos seis inesperados anos de guerra que, sem dúvida, assumiram proporções dantescas, em termos de baixas, crise econômica e comprometimento da imagem pública da monarquia, precipitando, assim, o início da campanha republicana, bem como a abolição. ${ }^{28}$ Como sintetiza Schwarcz, numa indagação que mostra bem a inversão processada:

A despeito da oscilação, a guerra terminava com uma vitória abalada pelo número de mortes e pela crueldade das batalhas. A imagem do imperador também saía arranhada; afinal qual seria o motivo dessa perseguição, que inclusive conseguiu emprestar à memória de López um caráter heroico e patriótico? ${ }^{29}$

Da guerra cruenta, alegorizada em dama fatal, Pedro Luís focalizou, com toda ambiguidade, a batalha do Riachuelo ("Impressões do combate de Riachuelo" é o subtítulo do poema), que marcou a guinada em favor da Tríplice Aliança ou "tríplice infâmia", como ficou conhecido o acordo. A seus versos, Castro Alves trataria de fazer a réplica poética com sua "Deusa incruenta", alegoria, agora, da imprensa, que contrapõe a razão ou ilustração como arma e alternativa à luta, sem guerra e derramamento de sangue,

26. LuIS, Pedro. Dispersos. Rio de Janeiro: Civilização Brasileira, 1934, p. 63.

27. Id., pp. 66-69.

28. Para uma síntese das teses sobre a Guerra do Paraguai ver: schwArcz, Lilia M. As barbas do imperador: um monarca nos trópicos. São Paulo: Companhia das Letras, 1998, pp. 295-318.

29. Id., p. 313 . 
segundo indica o título. Nisso, o autor de Espumas flutuantes seguia de perto a ideologia e a concepção liberais e emancipatórias vigentes em poemas como "O livro e a América", pautado pelo culto iluminista ao saber como via de acesso ao progresso.

Logo depois da geração hugoana de Pedro Luís, a alegoria feminina volta a marcar presença justamente em realistas ou baudelairianos como Fontoura Xavier, com quem ela assume um sentido bem diverso, fruto, sem dúvida, da fusão do ideal sexual e do político.

Em seu livro Opalas, de 1884, há uma seção sugestivamente intitulada "Musa livre", que redimensiona o significado do adjetivo aparentemente banal no contexto poético do século xix. Não custa lembrar que, por musa livre, era frequente denominar-se o licencioso ou francamente obsceno, como bem ilustram as Poesias livres de Laurindo Rabelo. Sem abandonar de todo esse sentido, Fontoura Xavier parece emprestar a tal adjetivo coloração mais claramente ideológica, no sentido do liberal ou mesmo do libertário. É assim que, na estância posta na abertura de tal seção, o poeta trata de figurar sua Musa livre como a porta-estandarte das raças que se espoja no pó das praças:

Sonhei-a no pó das praças

visão ou nuvem - saudei-a

Gonfaloneira das raças,

Sonhei-a no pó das praças,

Medeia à frente das massas,

Na mão o facho da Ideia,

Sonhei-a no pó das praças,

Visão ou nuvem - saudei-a.

Parece-me evidente que essa Musa livre, figurada como "Medeia à frente das massas", trazendo "[n]a mão o facho da Ideia", alegoriza os próprios ideais políticos e sociais do abolicionista, republicano ou mesmo socialista Fontoura Xavier, ${ }^{30}$ em versos, mais uma

30. Regina Zilberman chama a atenção para as ambiguidades do posicionamento político-ideológico, pensando não no seu republicanismo, mas no seu socialismo proudhoniano: "Fontoura Xavier denuncia a miséria pública, mas sua postura é sempre a de um aristocrata a quem repele a visão das distorções sociais. Nesse sentido, Fontoura Xavier assemelha-se muito a alguns personagens de Eça 
vez, ambivalentes, na medida em que a imagem feminina degradada no pó das praças é produto de um sonho acalentado pelo eu poético que a saúda. Essa ambivalência, reiterada pela alternância entre "visão ou nuvem", com que ela é qualificada, irá presidir também o primeiro poema homônimo da seção, portanto em estreita conexão com essa estrofe, justificando o sentido alegórico do conjunto. A "Musa Livre", que aparece nesse poema como "a cortesã da praça", faz lembrar, de imediato, a alegoria feminina da República, tal como figurada por poetas, pintores e caricaturistas nos anos imediatamente posteriores à Proclamação, inspirada decerto pelo exemplo francês, como bem nota José Murilo de Carvalho em A formação das almas:

De fato, bem depressa os caricaturistas passaram a usar a figura feminina para ridicularizar a República. É certo que os inimigos da República fizeram o mesmo na França. A virgem ou mulher heroica dos republicanos era facilmente transformada em mulher da vida, em prostituta. A diferença é que no Brasil essa representação foi a dominante, sendo usada mesmo pelos que inicialmente tinham apoiado o novo regime. O desapontamento refletido na conhecida frase 'Esta não é a república dos meus sonhos' rapidamente invadiu o mundo dos caricaturistas, ao mesmo tempo em que atingia os políticos da propaganda e os escritores. [...] A República, quando não se representava pela abstração, clássica ou romântica, só encontrava seu rosto na versão da mulher corrompida, era uma res publica, no sentido em que a prostituta era uma mulher pública. [...] Símbolos, alegorias, mitos só criam raízes quando há terreno social e cultural no qual se alimentarem. Na ausência de tal base, a tentativa de criá-los, de manipulá-los, de utilizá-los como elementos de legitimação, cai no vazio, quando não no ridículo. Parece-me que na França havia tal comunidade de imaginação. No Brasil, não havia (pp. 87-89).

Não se pode, todavia, esquecer que a "Musa livre" de Fontoura Xavier está incluída num livro que data de cinco anos antes da Proclamação... Seria possível, mesmo assim,

de Queirós: aqueles que encarnam homens ricos que, cultos e modernos, se emocionam perante a miséria, mas nada fazem para modificá-la. Pertence ao modernismo assumir posições socialistas, desde que essas não exijam mais que um poema, uma confissão ou uma carta referindo o testemunho político. Pela mesma razão, confunde-se muitas vezes a posição de cunho ideológico com a reflexão sobre a decadência da sociedade, situação que acaba por explicar a diferença de classes." Cf. "Fontoura Xavier: sua época e seus poemas". In: XAvier, Fontoura. Opalas. Porto Alegre: PUCrs, 1984, p. XXI. 
validar idêntica intenção alegórica e alcance crítico? Estaria o poeta pensando ainda na república como um ideal de regime de governo e na viabilidade de sua implantação aqui (inclusive depois de suas consequências nos países que o acalentaram)?

Seja qual for a resposta, o fato é que o poema encerra um contraste claro entre a atitude da "turba, inerte e lassa", que "desconhece a visão" da "cortesã da praça" e "sublima a prostituta", enquanto o eu poético adora e saúda deslumbrado essa alegoria, que empresta seu modelo não mais à Marianne, e sim a Marion, que, mais uma vez, como no poema castralvino, tanto pode se referir à prostituta de Jacques Rolla, de Musset, quanto à célebre cortesã Marion Delorme imortalizada por Hugo. A partir desse modelo, Fontoura Xavier converte, por fim, de forma ainda mais ambivalente, a Musa Livre na "Musa da Canalha"!

Vagner Camilo é professor de Literatura Brasileira da Universidade de São Paulo (USP) e autor de Risos entre pares: poesia e humor românticos (Edusp, 1997) e Drummond: da Rosa do povo à rosa das trevas (Ateliê, 2000). 